\title{
New Wave
}

\section{パルス磁場下の中性子散乱}

神戸大理 本河光博、野尻浩之

磁場はその線形応答としての帯磁率、非線形応答としての相転移など、物質の基本的性 質を調べる上で、温度、圧力と並ぶ重要な示強变数である。広い範囲にわたり磁場に対す る応答をみるためには強い磁場を発生させることが必要になるが、強磁場ではそのエネル ギ一密度が、例えば100Tでは $4 \times 10^{9} \mathrm{~J} / \mathrm{m}^{3}$ と大きいために発生には困難が伴う。しかしそ

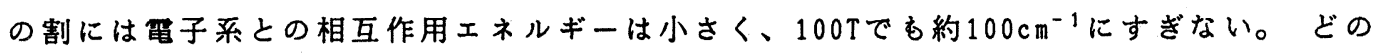
程度から強磁場と呼ぶかは、物理的内容から云うか、あるいは技術的制約から云うか、見 解によって異なるが、通常は容易に発生することが出来ない磁場という観点から考えて20 〜 $30 \mathrm{~T}$ 以上であろう。最近では技術の進歩とあいまって、定常磁場では約 $30 \mathrm{~T}$ 、パルス磁 場では非破壊です $80 \mathrm{~T}$ 、破壊を許せば $300 \mathrm{~T}$ 位の磁場まで発生できるようになり、またそ れに伴う物性研究む大幅に進んでいる。現在では強磁場物性という言葉も聞かれるほど多 くの研究がなされ、その活発さは研究の集約としての国際会議がかなり頻繁に行われてい ることからす同い知れる。さて強磁場の下に物質を置いたときその変化を見る手段として 色々の測定が行われている。筆者の一人はマイク口波をもちいたパルス強磁場磁気共鳴の 実験から強磁場の世界に入ったが、最もポピニラーな磁化测定、分光や非分光を含む光学 的実験、など多くの研究が強磁場中で行われている。

一方中性子散乱は物質の素励起において、 $\mathrm{k}=0$ 以外のモードを見ることの出来る手段 の一つとして最も重要な役割を担っている。そして強磁場との組合せに於て磁性体をはじ めとする諸々の物質の線形あるいは非線形の応答を中性子散乱でみることの重要性は誰し あ感ずるところである。表 1 は中性子散乱に用いられるンースと強磁場発生の方法の組合 せを書いた物である。ソースがパルスの場合ですステデイの場合でも定常磁場の方が使い やすいと思われる。現在一般には超伝導磁石で $20 \mathrm{~T}$ の磁場発生が可能となっているが、中 性子散乱に用いる場合、装置の制約から10 T 程度以上は困難のようである。また水冷式磁

中性子源

強磁場発生法

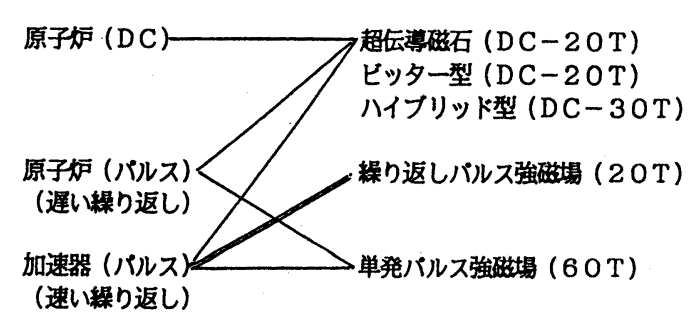

表 1 中性子源と強磁場発生法の組合せ 
石やハイブリッド磁石を用いて20、30 T 可能であるが、現在東北大学金属材料研究所に あるような大きな施設を中性子散乱実験装置と組み合わせて置くことはほとんど不可能で ある。前に強磁場というのを一応 $20 \mathrm{~T}$ 以上と述べたが、容易に得ることの困難な磁場とい う意味で、中性子散乱の実験の場合は $10 \mathrm{~T}$ 以上ならばその範疇に入るであろう。定常磁場 で10 T 以上が困難ならばパルス磁場ではどうであろうか。パルス磁場は比較的コンパクト な装置で強磁場を発生することが出来る。また冷却の問題す水冷式定常磁場に比べると格 段に容易である。通常パルス磁場というとコンデンサーなどのエネルギー源からマグネッ トに一発だけ放電する方式がとられ、次の放電まではコンデンサーの充電及びマグネット の冷却のために数分以上の時間が置かれる。すしも中性子源がパルスであれ、非常に強力 で、一発でデータがとれるようなものであれば、この単発パルス磁場と組み合わせて60T 位での実験は可能であろう。ウィーン工科大学では原子炉を瞬間的に暴走させて強い中性 子を得、パルス磁場の実験が行われたがまだデータをとる段階には至っていない。昨年 $\mathrm{K}$ E K でI C A N S - X I が開かれたとき、L A N Lでは一発でブラッグ反射がとれるよう な強力なスパレーション中性子源が数年以内に出来るという報告があったが、将来はこの ような強力なスパレーション中性子源との組合せが有望である。現在わが国に於いて一発 でブラッグ反射がとれるほどの強い中性子源はない。とはいえ手をこまねいてみている訳 にはゆかない。現状の中性子源でどの程度の強磁場実験が出来るか、それが我々に与えら れた課題である。パルス磁場の実験では短時間に大きく変動する磁場のピークの辺りだけ を用いるので原子炉によるステデイビームとの組み合わせはあまりメリットがなさそうで ある。即ちパルス中性子と同期をとって用いるのが最すスマートな方法と考えられる。現 在わが国で唯一利用できるK E N S パルス中性子を用いた場合、かなりの回数データの アキュムレーションが必要である。従って磁場の方もビームパルスと同期をとって繰り返 し発生できるむのが要求される。我々は数年前同じ加速器から発生されるパルス中間子ビ 一ムと組み合わせる目的で絽り返しパルス強磁場発生装置の開発を行っていた。これを中 性子実験にす応用したのが今回の我々の研究である。

ハード面の詳細に関しては別の論文”を見て頂くとして、我々の装置の仕様を述べる。 発生できる最高磁場は20 Tであるが、安全を見て18 T 以下で使う。2.5秒每の繰り返しで あるので全ビームパルスの1/40を用いることになる。即ち通常の実験より40倍時間がかる ことになるが弾性散乱の実験ならば十分実用になる。マグネットは水冷式で常温で使用さ れるので試料用クライオスタットだけをマグネットの中に挿入する。マグネットは図1の ようにゴニオメーターの上に水平に置かれ、水平面で回転できるが、現在の方法ではマグ ネットのロ径によって制限され可能な回転角はわずかである。また検出器は固定で入射ビ 一ムの方向に対して $2 \theta=10^{\circ}$ の方向にセットされている。中性子散乱はTOF法によって ブラッグの式を満足する波長を持つ中性子がカゥンターに到達する時刻に観測される。試 
料はマグネットの中に置かれ磁場の方向に対して固定されている。温度は液体へリウムを 流すことによって約 $4.2 \mathrm{~K}$ まで冷やすことが出来る。しかし試料が金属の場合は渦電流に よる発熱が問題となる。

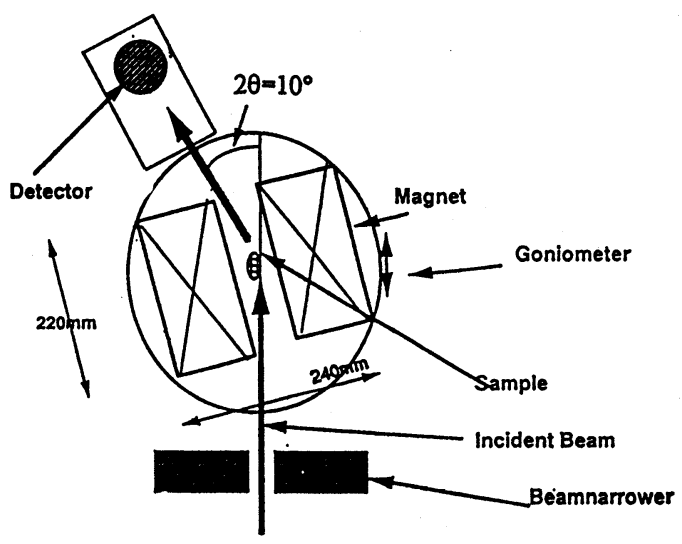

図 1 ゴニオメーター上のマグネット、試料及び中性子ビームの配置

この装置を最初に応用した実験としてPrCo2Si2の強磁場中での磁気構造の研究を紹介す る。この物質は $T_{N}=30 \mathrm{~K}$ 以下でモーメントが $\mathrm{c}$ 面内で強磁性的なので磁気構造に関しては c 軸にそったー次元モデルが適用できる。c 軸方向には $\mathrm{T}_{1}=9 \mathrm{~K}$ 以下では反強磁性的である が $T_{1}$ と $\mathrm{T}_{2}=17 \mathrm{~K}$ の間、 $\mathrm{T}_{2}$ と $\mathrm{TN}_{\mathrm{N}}$ の間ではそれぞれ $\mathrm{k}^{\prime}=0.926, \mathrm{k}^{\prime}=0.777$ のpropagation vector をすつ長周期構造をとることがゼ口磁場および低磁場での中性子散乱によって調べられて いた。一方磁場をかけた場合は強磁場磁化測定の実験によって Hc1=1.2T以下では反強磁 性的、Ho1 と $H_{02}=3.8 \mathrm{~T}$ の間および $\mathrm{H}_{02}$ と $\mathrm{Hs}_{\mathrm{s}}=12.2 \mathrm{~T}$ の間では上に述べた長周期構造になる という予想がたてられていた。それを確かめるのが我々の最初の実験である。まずゼ口磁 場で図2（a）のうに適当な方向からビームをあてると反強磁性構造に対しブラッグの条
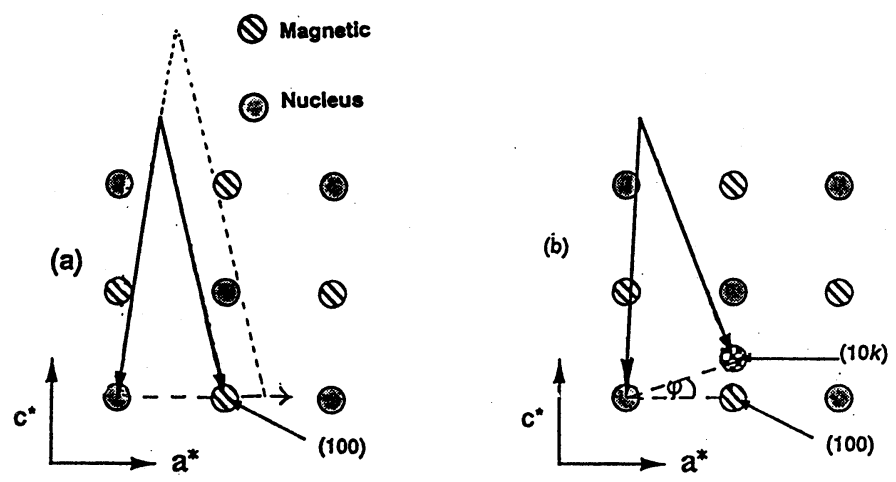

図 2 逆格子と入射及び散乱中性子の波数ベクトル 
件を満足する波長（約 $1 \AA$ ）に対応する時刻に図 3 のような散乱強度を観測する。その時刻 に同期させてHo1より高いパルス磁場をかけるとそのブラッグピークは消える。2 $\theta$ は固定 なので、そのままの位置で波長を掃引してす図2(a)の点線のようになり、逆格子で矢印 の方に掃引することになる。磁場中では長周期構造の逆格子点が図 $2(\mathrm{~b})$ の $(1,0, \mathrm{k})$ の位

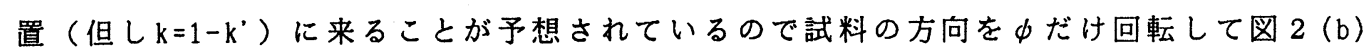
のような配置で磁場中の磁気散乱を観測することになる。そのときブラッグの条件から散

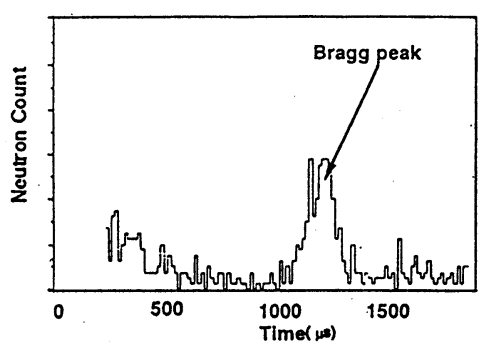

図 3 ゼロ磁場でのブラッグピーク

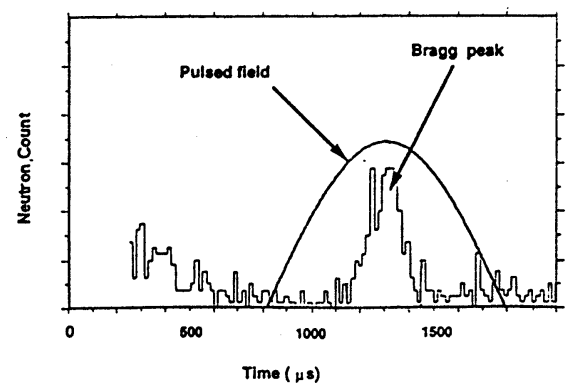

図 4 ブラッグピークの見える時刻 でのパルス磁場との同期

乱強度の見える波長、即ち時刻す予想され、図4のようにその時刻にパルス磁場がかかる ように同期をとる。(1.0.0.225)に対しブラッグの条件を満たす波長に対応する時刻に7.4 $\mathrm{T}$ のパルス磁場をかけると図 5 の様に散乱が見られるが、磁場を $5 \mathrm{~T}$ またはゼ口にすると それは消える。さらにそれがHsより高い磁場では消えることす確認した。図 6 は最終的 に得られた相図であるが、強磁場では温度が变化している。これは試料が金属であるため に生じる問題で、試料がバルクであるがぎりさけられない。温度を計算で評価することは

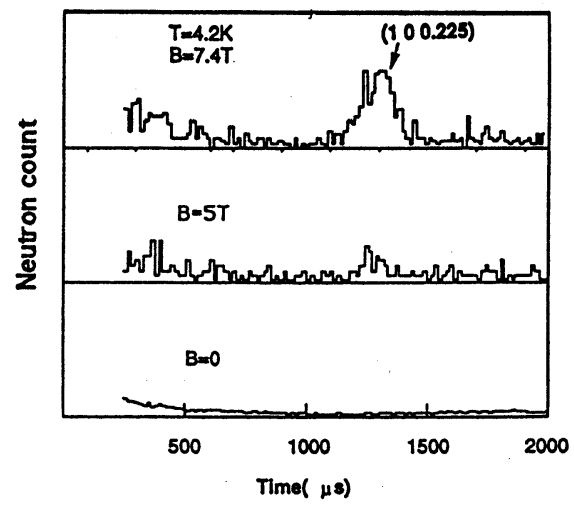

図 $57.4 \mathrm{~T}$ で見えるピークが磁場を 下げると消える

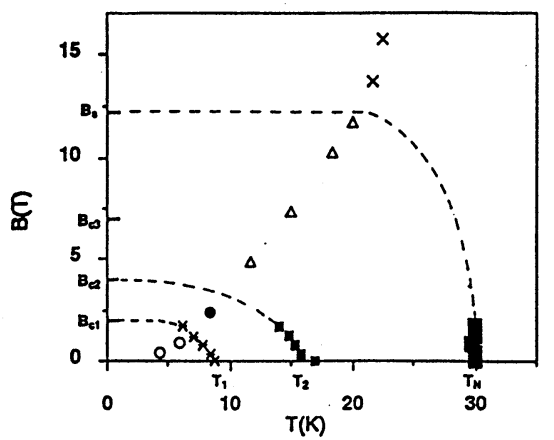

図6 得られた模式的な相図 $\times \triangle \bigcirc \bigcirc$ は実験点 
困難であるが、ゼロ磁場でのブラッグピークの強度が温度に依存するという効果を使って、 ブラッグピークの現れる直前に磁場が終了するようにタイミングを合わせその時の強度か ら温度を評価した。

このようにして磁化測定で予想された構造はパルス強磁場と中性子散乱の組合せによっ て確認されたわけであり、強磁場での中性子散乱実験の技術が一歩前進したと思われる。 しかしここで注意しなければならないことはブラッグピークの見える位置が予め分かって いる物に対してのみこの方法は有効であるということである。即ち構造が全く未知の物に 対してはどの時点でパルス磁場を同期させればよいか分からないという問題がある。それ を解決するためにはある範囲の $\mathrm{k}$ と波長を同時にカバーする測定が必要になる。図2 (a) のように散乱角が固定の場合は直線上にある点しかカバー できないが角度 $\alpha$ をカバーする位置敏感検出器 ( P S D )

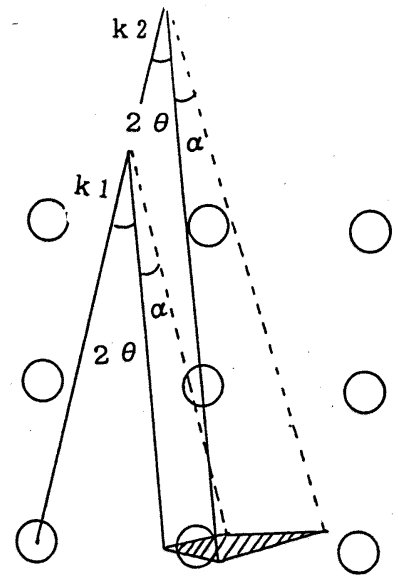

図 7 P S D でカバーでき る領域の模式図 を使うことによって図 7 の様に斜線部分をカバーすること ができ、さらにk から の間フラットであるような磁場をかければ、強磁場中で逆 格子点がこのエリアにある構造は必ず見えることになる。 そしてゴニオメーターで $\phi$ 変化させてゆけば全領域をカ バーすることになり未知の構造を決めることができる。現 在そのような目的で P S D の設置を行いつつある。同時に 数ミリ秒程度ピーク磁場がフラットであるようなフラット トップパルス強磁場の発生す計画している。さらにすっと 強度の高い材料を用いて最高磁場を $30 \mathrm{~T}$ まで上げるための 努力す行っている。また $2 \theta$ を大きくとる目的でスプリット 型の綎置きマグネットを開発中である。これにより分解能 が上がること、ガラスデワーが使えるので $1.4 \mathrm{~K}$ まで低温が 得られることなどメリットがあるが最高磁場は10数 Tし得 られないであろう。

以上のようなことから強磁場中性子散乱の実験が成功したというょりむしろようやく緒 についたというべきで、我々の試みはその可能性を明らかにしたという点で意義があるの ではないかと思われる。

\section{文献}

1) M. Motokawa, H. Nojiri, M. Uchi, S. Watanabe, H. Kawai and Y. Endoh: Proceedings of ICANS-XI in press. 